\title{
An anthropological approach to human remains from the gulags
}

\section{Élisabeth Anstett}

We owe respect to the living

To the dead we owe only the truth.

(Voltaire)

\section{Introduction}

Archaeologists and anthropologists specializing in the field of funerary customs have long been used to considering the degree of social, religious and political investment placed in the dead body. Ever since the pioneering work of Robert Hertz, we have known that the social treatment of corpses is based on a series of rituals that bring into play the full range of collective representations relating to the perpetuation of the group. ${ }^{1}$ These rituals frequently involve the use of temporary graves, as the final burial or cremation of the bodies is, in the societies studied by Hertz and in others, only the last stage of this process.

Few studies in this field, however, have dealt with collective burials. Anthropologists interested in the specific contexts of wars and epidemics ${ }^{2}$ have developed the notion of 'catastrophe burial', which relates to the simultaneous mass burial of large numbers of corpses as a result of natural disasters, famine, disease or conflict. ${ }^{3}$ Yet, up until very recently, the treatment of the bodies resulting from mass violence - or, for that matter, this extreme violence itself - has received little attention from anthropologists. ${ }^{4}$ 
However, a shift began with the large-scale exhumations undertaken in Bosnia and Spain, which shed new light on the fate of bodies in such situations and led anthropologists to consider the agendas underpinning a set of practices which, in a real sense, link the killers to their victims even after the death of the latter, and which are consequently all the more revealing of the processes governing the entry into - and exit from - violence. Studies such as those of Francisco Ferrandiz on Spain ${ }^{5}$ and Elisabeth Claverie on Bosnia ${ }^{6}$ have thus focused on the fate of the dead after their death, seeking to reveal by whom, how and exactly when the corpses were destroyed, buried, hidden or, on the contrary, displayed to the living/survivors. In so doing, these studies have revealed that the legal and symbolic status given to human remains in situations of mass violence can vary enormously, from that of material evidence to that of simple detritus. In this respect, the example of the violence perpetrated in the Soviet period is particularly revealing in a number of ways.

\section{A long-lived and lethal institution}

It is important to note from the outset that the deployment of violence through the gulag occurred on a historical, geographical and sociological scale that has rarely been equalled. The concentration camps which were first set up in the early months of the Bolshevik regime and subsequently spread across Russia and throughout the USSR would imprison, over the seventy years of their existence, around 15 million people. The precise nature of these camps, which were placed between 1930 and 1956 under the aegis of a dedicated central administration, the gulag, ${ }^{7}$ varied greatly according to specific local situations and prevailing historical circumstances, as these factors largely dictated the living conditions (and therefore life expectancy) of detainees, depending on whether, for example, they were employed in the agricultural or industrial sectors, or in mining, or imprisoned during particularly harsh periods of famine or war. ${ }^{8}$

The stated aim of this dedicated central administration was to correct deviant minds through processes of deportation, incarceration and forced labour which made use of terror and extreme violence at every stage, with the objective, it must be emphasized, not of destroying the detainees, but rather of re-educating them. ${ }^{9}$ For in the gulag, the physical and psychological enslavement of 
human beings was seen above all as a means of correction, albeit involving the death by exhaustion of the recalcitrant and the weak. In the camps, the wearing down of the body through work and hunger was the main tool ${ }^{10}$ of 'correction' (ispravlenie), taken here to mean re-education. This said, the gulag was always a polymorphous and shifting institution whose boundaries were difficult to locate. It remains an object without any easily defined borders or contours.

\section{An object with no clear beginning or end}

Any attempt to locate the precise beginning and end of the gulag system thus faces considerable difficulties. Should 7 April 1930, the date of the decree by the Politburo setting up a central administration devoted to the running of the 're-education through labour' camps scheme, be taken as the date of the birth of the Soviet concentration camp system? Or should we consider that the latter began with the readiness, stated as early as January 1918, to use deportation, internment in concentration camps and forced labour as the principal means of dealing with political opposition? ${ }^{11}$ What we can be sure of is that this rapidly established and long-lived coexistence of spaces of detention controlled by the state security organs alongside, and on the margins of, a prison system answering to the courts, constitutes the primary distinguishing feature of the gulag system. ${ }^{12}$

Similarly, should the end of the system be seen as occurring with the dismantling of the general administration of the camps at the end of 1956, or only with the large-scale release of dissidents by M. Gorbachev in 1986, which marked the end of this political instrumentalization of criminal justice and medicine? For a focus on the Stalinist period alone necessarily tends to neglect the question of the extraordinary longevity of the gulag system and, more generally, of the continuing practice, throughout the Soviet period, of sentencing individuals to deportation, internal exile and forced labour. The issue of the highly porous nature of the spaces of the gulags also needs to be addressed.

The stereotypical image of the camps as physically isolated and cut off from society ${ }^{13}$ masks the true size of the net cast by these spaces, a net spread all the wider owing to the use of the gulags for large-scale civil engineering works from the 1920s onwards. This Soviet system can for this reason truly be said to cover the entirety of the territory of the former USSR ${ }^{14}$ The economic exploitation 
of the Soviet concentration camps thus helped to weave the gulags into the most ordinary spaces of everyday life: factories and hospitals, universities and residential buildings, roads and canals, mines, forests and farms. ${ }^{15}$ Any part of the territory of the former USSR is liable to harbour traces of this aspect of the country's past. The high degree of communication between these places of detention and the rural and peri-urban locations of the industrial or agricultural installations to which detainees were led daily under escort was another enduring characteristic of the areas surrounding the camps, making an exhaustive cartography of the gulags virtually impossible.

The question of the social groups affected by the gulags is more complex still, given the successive generations of protagonists involved in a sprawling system which existed in a multitude of forms arguably from the beginning of the 1920s to the end of the 1980s. The estimated total number of people incarcerated therefore varies from around 10 to up to 20 million, according to the period under consideration, the particular courts and legislation involved, and the type of sentences in question. ${ }^{16}$ However, after long years of controversy, and based on the most recent research, historians are now in general agreement that the gulag system caused the death of around 2 million people, a figure to which must be added the 800,000 murdered by the Soviet regime during the great purges. ${ }^{17}$ Unlike the Nazi extermination camps, the history and sociology of which have been the subject of considerable amounts of research, a thorough sociological study of the gulag system has yet to be conducted. This is due in no small part to the difficulties involved in identifying its victims.

\section{Confiscated bodies}

One of the defining characteristics of the political violence of the Soviet period was that the bodies of its victims were never returned to their loved ones. The confiscation of bodies by the state was established from the outset as the standard procedure for the treatment of the corpses of detainees, following explicit instructions given in a circular issued by the supreme tribunal of the Pan-Russian Executive Committee, dated 14 October $1922 .{ }^{18}$ This stipulated:

The body of the shot individual must not be returned to anyone; it will be buried without any formality or ritual, dressed in the clothes worn 
when shot, on the site of the execution of the sentence or in any other available place, in such a way as to leave no trace of burial or, alternatively, it will be sent to the mortuary for incineration. ${ }^{19}$

These provisions were progressively applied to all places where deaths occurred (prisons, camps, hospitals), irrespective of how prisoners died: not just for executions, but also for deaths caused by homicide, accidents or illness. It was therefore the Soviet state, and more specifically the various administrative departments of the camps placed under the direct and sole authority of the state security organs (the GPU, NKVD or KGB, according to the period in question) which had the job of dealing with prisoners' bodies and systematically ensuring that they would 'leave no trace'.

This explicitly stated desire on the part of the state not to hand back bodies may be seen to fit in a number of ways into the logic of a corrective re-education of 'deviant' minds by means of deportation and forced labour. For the only prisoners who could leave the gulag and return to normal Soviet life were those who had been 'brought into line' through work. The corpses of those who had failed to do so were thus quite logically and unceremoniously disposed of by the state through burial, immersion in water, cremation, or simply being abandoned in remote areas.

\section{Burial, immersion in water, incineration, abandonment}

Several techniques were thus used to dispose of the bodies of dead detainees 'in such a way as to leave no trace'. Individual burial was rare, tending to be used in networks of camps that had functioned for a sufficiently long period for their sites to have become permanent. In such cases, one finds funerary mounds, usually containing unmarked graves, but sometimes bearing the dead prisoner's number engraved on a piece of metal (taken from a tin can), or on a wooden stake. ${ }^{20}$

Mass burial was the method most frequently used. To this end, each administrative unit of the gulag system (Ourallag, Dmitlag, Volgolag, etc.) had gravedigging brigades composed of detainees assigned exclusively to logistical tasks relating to burial. The burial pits were dug directly on land administered by the state security services, in areas near to the sites of detention. The frequency at which they were dug was dependent on the rate of mortality in the camp, which could vary greatly. ${ }^{21}$ 
These mass graves were more often than not dug by hand, as attested by Dimitri Vassilievitch Ostroumov. ${ }^{22}$ Born in Moscow in 1924, he was arrested in Leningrad in August 1942 and imprisoned there until February 1943. Sentenced to ten years' forced labour, he was initially placed in the Volgolag at Uglitch, then transferred to the Volgolag at Rybinsk, where he would remain until 1948, before being transferred to Norilsk, where he spent the rest of his sentence. While mainly given general work duties on the Rybinsk site, such as tree-felling and log-cutting, the young man was also assigned to the Mogilsikiki (gravediggers') brigade. He describes having thus participated in the daily digging of graves which could contain twenty to thirty corpses, situated on the outskirts of one of the civilian cemeteries of Rybinsk. However, these pits were occasionally dug using dynamite or ammonium nitrate in camps situated in polar or arctic regions, a practice which even gave rise to a specific term, ammonalniki, which denoted these pits dug in the permafrost using explosives, into which the corpses of prisoners were thrown once winter was over. ${ }^{23}$

Immersion was also used at times in zones where, in winter, the ground was frozen too hard to be dug. The bodies of detainees were thus thrown into streams, rivers, lakes or the sea through holes hacked into the ice, as documented by the camp guard Danzig Baldaev in his sketchbooks. ${ }^{24}$

Repeated references have also been made to corpses being simply abandoned. Prisoners could die outside the camp perimeter, either during routine movements (their daily work often involved long and arduous journeys) or during transfers from one establishment to another (life in the camps was punctuated by frequent transfers of prisoners, on foot or by train). The organization of the vast Soviet camp network was not infallible, and there were times when bodies were simply left where they had fallen. One of the most striking examples of this practice is documented by the historian Nicolas Werth in his study of the Island of Nazino, nicknamed the 'Island of Death' or 'Cannibal Island'. ${ }^{25}$

In what constituted something of an exception to the rule, however, detainees' bodies were cremated in Moscow at the newly opened Donskoï cemetery, where the crematorium, which began operating in 1927 (and continued up to 1970), was used from 1935 onwards to incinerate some of the victims of Stalin's purges. The rate varied: while 'only' 107 bodies were clandestinely cremated in 1937, the bodies of all the people executed in Moscow in 1940 were cremated on this site. ${ }^{26}$ The crematorium at the new Donskoï 
cemetery in which these cremations were carried out was removed in 1970, and the church which had housed it was restored and reinstated as a place of worship. However, several commemorative plaques left by delegations from various countries (including Japan, Germany, Poland and Korea) act as reminders that the Soviet capital was the scene not only of mass murders, but also of mass cremations, well before the ovens of the Nazi camps.

The vast majority of corpses from the gulags, however, remain buried in the vicinity of the camps. And so, given that the camps were for the most part situated in the vicinity of urban conglomerations, the map of the gulags precisely matches the map of the population of the Soviet Union. Yet in spite of the proximity between the Soviet population, the camps and their mass graves, there has never been a systematic policy of locating burial sites (whether at local, regional or federal level), and no official inventory of mass graves has ever been drawn up. While the map of the camps has now been established, ${ }^{27}$ the map of the mass graves of the gulags has yet to be drawn.

\section{The return of human remains}

The facts, though, stubbornly refuse to go away, and it is impossible to ignore the skeletons, hidden away for so long, that are now reappearing.

The reappearance of human remains can occur by chance due to a variety of factors, whether climatic (forest fires, floods, drought) or geological (landslides, soil erosion) in nature; it can also be the result of building works such as road widening, the construction of new buildings, or excavation beneath existing buildings to create car parks. Accidental and unexpected discoveries are just as likely to occur out in the countryside as they are on the outskirts of urban areas or in the middle of cities.

Thus, on 4 October 2007, workers on a construction site beneath an old apartment building in the centre of Moscow which was to be converted into a shopping centre discovered the remains of thirtyfour bodies and a rusty pistol. ${ }^{28}$ The obvious age of the skeletons and the bullet impacts visible on the skulls, indicating that they had been shot at point-blank range, along with the fact that the building was just opposite the infamous 'Rasstrelny Dom', ${ }^{29}$ led the local police to presume that the remains were probably those of victims of the Great Purges of 1937-38. The spokesman for the 
regional coroner's office, however, opined that they might have 'died as a result of illness ... during the Tsarist era'. The official report on the cause of death, which should have been released at the end of the inquest, has yet to be made public. In June 2010, meanwhile, a mass grave containing 500 skeletons ( 3.5 tonnes of bones in total) was discovered by workers building a road on the outskirts of Vladivostok. ${ }^{30}$

However, human remains can also reappear as a result of intentional excavations carried out to this end by various actors motivated by a dual desire both to bring the long-hidden dead to light and to give victims a proper reburial. Those who are attempting to locate sites of clandestine burial may be lone individuals (often interested in local history) whose motivations are frequently linked to very particular contexts of strong personal significance. Occasionally, Russian or sometimes even foreign institutions (as in the case of the Katyn massacre, in which various Polish institutions were involved) conduct searches. The Orthodox Church has thus been actively involved in the exhumations carried out on the site at Butovo in the Moscow suburbs, where mass graves were thought to contain the bodies of priests and monks, in order to identify these bodies and see to their reburial. ${ }^{31}$ Some NGOs have also organized research expeditions along the same lines as the ethnographic and archaeological expeditions carried out in the nineteenth century by scientists and folklorists. Viatcheslav Bitioutskij, the regional organizer in Voronezh for the NGO Memorial has for more than twenty years (following the discovery in September 1989 of a first mass grave) been conducting a slow and painstaking investigation of the clandestine burials carried out in forested areas near Voronezh. This search has already led to the discovery of fifty-three pits containing the remains of 2,361 individuals, who have all subsequently been given a religious burial. Out of these, it has been possible to identify only a single group of forty-eight victims, and this was due to a stroke of luck: one of the victims had his arrest warrant in his pocket. ${ }^{32}$

The problem of identifying these bodies is the main stumbling block encountered by all procedures of exhumation (and reburial) in Russia, for while the archives of the state security organs meticulously document the details of the trial and sentencing process, they say absolutely nothing about the locations and techniques used to dispose of the bodies of executed prisoners (burial, cremation, immersion in water, abandonment). Although exhumations frequently do provide indications as to the historical context of their 
deaths, allowing a date to be assigned to the latter, the skeletons are rarely identified.

The treatment of human remains following their exhumation and the legal status assigned to them as individuals pose a new set of legal and political problems of a particularly thorny nature. It is by no means rare, then, for remains from gulag mass graves to be reburied outside of any legal framework, the coroner in question having either refused to open an inquest (thus avoiding having to make a decision regarding the legal status of the bones, which might place the responsibility for dealing with them on the state) or ruled that the human remains which have been discovered are archaeological artefacts without commercial value, and hence without national historical value, thereby absolving the state of any responsibility for them and allowing those who found them to do with them as they please. The reappearance of human remains several decades after the disappearance, then, poses Russian society with a series of complex and entirely new questions.

\section{The status and social functions of human remains}

These reappearances thus have a retrospective effect, forcing society to look back upon the long years during which it had lived alongside these skeletons strewn across its territory. It is therefore apposite in this context to examine the symbolic and social mechanisms which have legitimized such a long presence-absence of human remains on such a massive scale, and have made it possible to draw a veil of silence over this lengthy period spent in the company of countless mass graves. In this respect, whole sections of the social history of the USSR have yet to be written. An examination of this geography of shadows, this geography of the implicit (with all its whispered knowledge, its rumours), which was maintained over many decades and is now resurfacing due to a change in the political situation that also corresponds to a generational shift, surely constitutes one of the most promising avenues for future research in this area. In an academic context, a true sociology of denial, which Stanley Cohen has started to explore, stands to gain much from close attention to the ways in which multiple avoidance strategies, in particular those of a linguistic nature, have been deployed by, and subsequently become engrained within, Russian society. ${ }^{33}$

Indeed, the context of these reappearances corresponds in a number of ways to a return of the repressed. Following on from the 
work begun by Cara Krmpotich, Joost Fontein and John Harries on the agency of bones, in a very real sense, to become social actors, and in the light of what may be seen in Russia, it is necessary to consider not only what the return of human remains reveals to Russian society about its own past, but also which parts of the structures erected to maintain a consensus of silence around the presence of mass graves are imperilled by the discovery of those graves and their contents. ${ }^{34}$

Looking forward from these reappearances, meanwhile, it is equally important to study the agendas behind, on the one hand, the negotiations over the legal status of human remains (and consequently their ultimate fate) and, on the other, the actual practices of reburial. For the extremely prominent position that religious elements are now coming to occupy (both in the rituals being performed and in the memorials being erected), along with political and ideological interests (with the progressive growth of nationalist agendas in many territories born out of the disintegration of the USSR), forces us to consider, following on from the pioneering work by Katherine Verdery, the political and religious life of human remains, and to embark upon a true social anthropology of the practices of reburial in post-Soviet spaces. ${ }^{35}$

\section{What do these bones represent?}

Yet the return of the dead brings with it a set of radical methodological and epistemological questions for those studying post-Soviet societies.

If indeed we wish to pursue an analysis of this 'dark side of modernity' ('face obscure de la modernité'), to use Jackie Assayag's expression (2007), how can we 'come to an understanding' ('faire avec') and deal with secrecy? ${ }^{36}$ How can we distinguish between what has been known but silenced, or simply believed without ever having been seen, and how can we delimit the nebulous role of the collective imagination? On the ground, the richness and highly 'talkative' nature of archives form a counterpoint to the elisions, euphemisms, allusions and metaphors which characterize the testimony of survivors and neighbours of the camps alike, greatly complicating the task of the ethnographer when it comes to exploring a phenomenon of denial on such a scale.

Moreover, is the observational distance so prized by anthropologists still tenable when observing social configurations that are so 
deeply marked by extreme violence? In distancing ourselves do we not run the risk of remaining on the margins, of missing the true meaning of social behaviours? On a deeper level, how much importance should be attached to 'axiological neutrality', that founding principle of investigative work, when faced with the disgust, the fear or the incredulity which sometimes seize the researcher confronted with the material traces of the destruction of bodies? And how do we force ourselves to think the unthinkable, given that the logical and social frameworks which made the production of death on such a scale possible seem to escape any articulations of ordinary reasoning?

As regards the question of ethics, how do we avoid voyeurism and provide an intelligible account of the facts without sliding into obscenity? And, insofar as the victims are survived by executioners as well as witnesses (whose potential collaborative role in the violence is always far from clear at first), and given that the ethical principles of ethnographic investigation demand that we 'do not prejudice' our interviewees, how can we record the words of killers and of their potential accomplices? Finally, what ought to be the relationship between the researcher and human remains when the status bestowed upon these by the society under study is that of 'archaeological artefacts without commercial value', or even of simple refuse? Any researcher who carries out a real exploration of a field such as that of the traces left by practices of extreme violence, and in particular that of the social uses of human remains, can only hope to arrive at a series of subtle compromises, always unstable and always unsatisfactory, and often marked by half-retractions and false victories.

However, insofar as anthropology gives equal weight to what is left unsaid as to what is explicitly stated, the discipline is indeed able to shed light upon the densest and sometimes most illegible elements that acts and words may conceal within themselves. It thus allows us to establish a documented inventory of the present state of a society. The true challenge facing any anthropologist who really seeks to understand these mass crimes and reconstitute the long biography of their mass graves, as a witness to the witnesses of violence, confronted like them with the confusion or illegibility of traces, is that of accepting to work with tenuous clues and faltering trails. For this is the only way to establish a template for a true social symptomatology, which constitutes the only hope we have of exerting a truly beneficial influence on the discourse of legal experts and historians. 


\section{Practices of concealment and their effects}

The application of these practices of concealment to the evidence of the gulag in turn poses the anthropologist, as well as the historian and the legal specialist, with a set of questions that are essential to understanding the social effects of extreme violence. However, in order to pursue this line of investigation further, it is necessary to clarify certain key points.

Firstly, as the case of the USSR clearly demonstrates, one of the principal social effects of the confiscation of bodies is to maintain the societies in question in a state of deferred mourning, ${ }^{37}$ and this mourning can be deferred for a very long time indeed. For it is still practically impossible for the descendants of the 2 million who died in the gulags (some of whom perished in the 1930s) to know the date of the deaths of their loved ones, the conditions under which these occurred or the place of their burial, despite the fact that they died inside a state institution. The victims of this mass violence are in this respect comparable to the 'disappeared' of the Latin American dictatorships. It is also important to remember that the key feature of the crime of disappearance (characterized by the absence of a body), as opposed to that of homicide (where the corpse is the first piece of evidence pointing to the crime), is that it continues for as long as the victim remains undiscovered. On a purely legal level, then, mass violence which is accompanied by the confiscation, concealment or destruction of bodies must be considered as being distinct from mass murders committed without confiscation, and treated as a specific category of violence perpetrated over an extended period.

This first set of points shows the need for a more sustained investigation of the specific features and the wider implications of these practices of concealment in comparison with radically different practices such as the abandonment or indeed the intentional display of corpses. This is where the importance of a comparative analysis of the production of violence becomes clear.

By comparing the Soviet case with other practices of destruction or concealment, as applied, for example, in the context of the Holocaust through the use of specially designed cremation ovens, ${ }^{38}$ under the Uruguayan dictatorship with the implementation of 'Operation Carrot', ${ }^{39}$ or in the former Yugosalvia with the widespread use of secondary or tertiary burials,${ }^{40}$ it is possible to see that wherever the practice of confiscation of bodies by the state occurs, it is accompanied by the mobilization - or indeed the creation - of 
technological devices or practices which are specifically designed to facilitate the hiding of bodies, and which are distinct from techniques of killing.

This link between mass violence and technological innovation emerges within a historical context, that of the twentieth century, which was particularly marked by the growing complexity of devices used (going, for example, from using spades to using bulldozers to dig burial pits) and by the importance of transfers of technology. It should be noted, for example, that the same German firm, Topf \& Söhne, which in 1926 designed the crematory ovens that would allow the Soviet state to carry out the clandestine incineration of the victims of the purges would, at the beginning of the 1940s, design crematory ovens able to function day and night and which were installed most notoriously at Auschwitz-Birkenau.

The circulation of techniques and knowledge is thus revealed as being at the heart of practices of the mass destruction of bodies, not merely at the stage of killing, but also at the subsequent, additional stages of the confiscation of bodies and the concealment of traces. These are all questions that have yet to be studied in detail in order to measure their true effects and social implications.

\section{Notes}

1 R. Hertz, 'Contribution à une étude sur la représentation collective de la mort', L’Année Sociologique, 10 (1907), pp. 48-137.

2 C. Rigeade, Les Sépultures de catastrophe: approche anthropologique des sites d'inhumations en relation avec des épidémies de peste, des massacres de population et des charniers militaires (BAR International S1695, internal report, 2007), p. 129; M. Signoli, D. Chevé, P. Adalian, G. Boëtsch \& O. Dutour, La Peste: entre épidémies et sociétés (Florence: Firenze University Press, 2007); M. Signoli, 'Archéo-anthropologie funéraire et épidémiologie', Socio-anthropologie, 22 (2008), at http:// socio-anthropologie.revues.org/index1155.html (accessed 2 October 2012).

3 O.Dutour, 'Traces de vies disparues:l'anthropologue face aux charniers', Socio-anthropologie, 12 (2002), at http://socio-anthropologie.revues. org/index146.html (accessed 27 November 2013).

4 J. Assayag, 'La face obscure de la modernité', L’Homme, 170 (2004), pp. $232-43$.

5 F. Ferrandiz, 'Exhuming the defeated: civil war mass grave in 21st century Spain', American Ethnologist, 40:1 (2013), pp. 38-54.

6 E. Claverie, 'Réapparaître. Retrouver les corps des personnes disparues pendant la guerre en Bosnie', Raisons Politiques, 41:1 (2011), pp. 13-31. 
7 The acronym GULag (Glavnoe Upravlenie Lagerei: principal camp authority) initially designated the administrative authority which oversaw the ITL (Ispravitel'no-Trudovoj Lager), the 're-education through work' camps. The term came to be used metonymically to refer to the institution as a whole, covering all the spaces of the Soviet concentration camp system.

8 An exhaustive list of the camps which operated between 1923 and 1960, giving details of dates of operation, numbers of personnel and detainees and their activities, has been published in Russian: N. Ohotin \& A. Roginski, Sistema ispravitel'no-trudovyh lagerei v SSSR, 1923-1960 (Moscow: Zvenia, 1998).

9 The camps were referred to as ITLs (Ispravitelno-trudovye lageria): literally, 're-education through work' camps (sometimes translated as 'correction by work' camps).

10 A. Becker, 'Exterminations: le corps et les camps', in J. J. Courtine (ed.), Histoire du corps. Volume 3: Les mutations du regard, le XXe siècle (Paris: Le Seuil, 2006), pp. 321-39.

11 A. Kokurin, N. Petrov \& V. Sostakovic, Gulag Glavnoe Upravlenie Lagerei 1917-1960 (Moskva: Demokra, 2000).

12 O. Khlevniuk, The History of the Gulag: From Collectivization to the Great Terror (New Haven: Yale University Press, 2000).

13 The work of Alexander Solzhenitsyn contributed to the popularization of the image of the gulag as an archipelago of islands, just as much as it raised awareness of its real nature.

14 See the analyses by the geographer R. Brunet, 'Géographie du goulag', L'Espace géographique, 3 (1981), pp. 215-32, and the work of the 'Mapping the Gulag' research programme, led by Judith Pallot (Oxford University), at www.gulagmaps.org (accessed 26 November 2013).

15 For an analysis of the involvement of the gulag in the Soviet economy, see G. M. Ivanova (ed.), Labor Camp Socialism: The Gulag in the Soviet Totalitarian System (New York: M. E. Sharpe, 2000).

16 For a rapid overview of the debates surrounding the number of victims of the Soviet camps, see the appendix to Anne Applebaum, Gulag a History of the Soviet Camps (London: Penguin Books, 2003), pp. 515-22.

17 See chapter 10 , 'Le phénomène concentrationnaire soviétique au $\mathrm{xx}^{\mathrm{e}}$ siècle', of N. Werth, La Terreur et le désarroi: Staline et son système (Paris: Perrin, 2007), pp. 199-221, in particular the table on p. 221.

18 The administrative ancestor of the Supreme Soviet of the USSR, the Pan-Russian Executive Committee (PREC) constituted the highest executive institution of the state.

19 PREC circular of 14 October 1922 as quoted in E. Jemkova, 'Les répressions staliniennes à Moscou et les lieux d'inhumation de masse', in É. Anstett \& L. Jurgenson (eds), Le Goulag en héritage: pour une anthropologie de la trace (Paris: Pétra, 2009), p. 115. Emphasis added.

20 See the photographs taken by Ivan Panikarov to accompany his article 'Le chemin s'arrête-t-il là?', in Anstett \& Jurgenson, Le Goulag en héritage, pp. 131-41. 
21 Memorial, a non-governmental organization (NGO), has begun drawing up an inventory of the mass graves sited on the territory of the former USSR. Its website, Gulagmuseum.org, contains a section devoted specifically to burial sites entitled 'Nekropoli', but, as of November 2013, it had only 522 entries. See http://gulagmuseum. org/search.do?objectTypeName $=$ necropolis \&page $=1$ \&language $=1$ (accessed 24 November 2013).

22 Memorial archives, Fond 1, delo 3449, opis 1.

23 For further explanation of gulag vocabulary, see J. Rossi, Le Manuel du goulag (Paris: Le Cherche Midi, 1997).

24 D. Baldaev, Drawings from the Gulag (London: Fuel, 2010). See the drawings on p. 89 and following, in particular that on p. 95.

25 N. Werth, L'Île aux cannibales: 1933, une déportation-abandon en Sibérie (Paris: Perrin, 2006).

26 The number of clandestine cremations carried out at the Donskoï cemetery was more than 1,500 (probably nearer 1,800) according to estimates based on the archives of the state security organs. See Jemkova, 'Les répressions staliniennes à Moscou', p. 123.

27 See the animated maps created by the group of geographers led by Judith Pallot at www.gulagmaps.org/maps (accessed May 2014).

28 See the report by the news agency Reuters dated 4 October 2007 and circulated by various media outlets, including The Guardian - see www. guardian.co.uk/world/2007/oct/05/russia.international (accessed 25 November 2013).

29 Referred to as the 'House of Execution', the building at 23 Nikolskaya Street housed the Military College of the Supreme Tribunal of the USSR, which, in Moscow alone, sentenced more than 40,000 people to capital punishment. It is also significant that the building site at which the bodies were found was situated just a few blocks away from the Lubyanka, the former headquarters of the NKVD (Narodnyy Komissariat Vnutrennikh Del, the People's Commissariat for Internal Affairs, responsible for the state security services and secret police), and current headquarters of the FSB (Federal'naya sluzhba bezopasnosti Rossiyskoy Federatsii, Federal Security Service of the Russian Federation, the direct successor to the USSR's Committee of State Security, or KGB).

30 See www.themoscowtimes.com/news/article/stalin-era-grave-yieldstons-of-bones/408048.html (accessed May 2014).

31 See the article by K. Rousselet, 'Butovo: la création d'un lieu de pèlerinages sur une terre de massacres', Politix, 20 (2007), p. 55-78. For a bibliography of historical research on this site, see the article by F.-X. Nérard for the online Encyclopaedia of Mass Violence entitled 'The Butovo shooting range', at www.massviolence.org/The-ButovoShooting-Range? artpage $=6$ (accessed May 2014).

32 See V. Bitioutskij, 'Tragiceskij pamiatnik bolchogo terrora v Voroneje', 30' Oktiabria, 103 (2011), pp. 8-9.

33 S. Cohen, State of Denial: Knowing About Atrocities and Suffering (Cambridge: Polity Press, 2001). 
34 C. Krmpotich, J. Fontein \& J. Harries, 'The substance of bones: the emotive materiality and affective presence of human remains', Journal of Material Culture, 15:4 (2010), pp. 371-84.

35 K. Verdery, Political Lives of Dead Bodies: Reburial and Post-socialist Change (New York: Columbia University Press, 1999).

36 J. Assayag, 'Le spectre des génocides', Gradhiva, 5 (2007), pp. 6-25, http://gradhiva.revues.org/658 (accessed 16 April 2013).

37 É. Anstett, 'Mémoire des répressions politiques en Russie postsoviétique: le cas du Goulag' (17 July 2011), Online Encyclopedia of Mass Violence, at www.massviolence.org/Memoire-des-repressionspolitiques-en-Russie-postsovietique (accessed 5 October 2012).

38 R. J. van Pelt, The Case for Auschwitz: Evidence from the Irving Trial (Bloomington: Indiana University Press, 2002).

39 J. Lopez Mazz, 'Historias desaparecidas y re aparecidas: el caso de Uruguay', in A. Zaranquin, M. Salerno \& C. Perosino (eds), Historias desaparecidas: arqueología, memoria y violencia política (Cordoba: Brujas, 2012), pp. 45-60.

40 Claverie, 'Réapparaître'.

\section{Bibliography}

Anstett, É., 'Mémoire des répressions politiques en Russie postsoviétique: le cas du Goulag' (17 July 2011), in Online Encyclopedia of Mass Violence, at www.massviolence.org/Memoire-des-repressions-politiquesen-Russie-postsovietique

Anstett, É. \& L. Jurgenson (eds), Le Goulag en héritage: pour une anthropologie de la trace (Paris: Pétra, 2009), from the series 'Sociétés et cultures postsoviétiques en mouvement', directed by M. Laruelle and V. Symaniec

Applebaum, A., Gulag a History of the Soviet Camps (London: Penguin Books, 2003)

Assayag, J., 'La face obscure de la modernité', L'Homme, 170 (2004), pp. 232-43

Assayag, J., 'Le spectre des génocides', Gradhiva, 5 (2007), pp. 6-25, http:// gradhiva.revues.org/658

Baldaev, D., Drawings from the Goulag (London: Fuel, 2010)

Becker, A., 'Exterminations: le corps et les camps', in J. J. Courtine (ed.), Histoire du corps. Volume 3: Les mutations du regard, le XXe siècle (Paris: Le Seuil, 2006), pp. 321-39

Bitioutskij, V., 'Tragiceskij pamiatnik bolchogo terrora v Voroneje', 30' Oktiabria, 103 (2011), pp. 8-9

Brunet, R., 'Géographie du goulag', L’Espace géographique, 3 (1981), pp. 215-32

Claverie, E., 'Réapparaître. Retrouver les corps des personnes disparues pendant la guerre en Bosnie', Raisons Politiques, 41:1 (2011), pp. 13-31

Cohen, S., State of Denial: Knowing About Atrocities and Suffering (Cambridge: Polity Press, 2001) 
Dutour, O., 'Traces de vies disparues: l'anthropologue face aux charniers', Socio-anthropologie, 12 (2002), at http://socio-anthropologie.revues. org/index146.html

Ferrandiz, F., 'Exhuming the defeated: civil war mass grave in 21st century Spain', American Ethnologist, 40:1 (2013), pp. 38-54

Héritier, F., De la violence II (Paris: Odile Jacob, 1999)

Hertz, R., 'Contribution à une étude sur la représentation collective de la mort', L’Année Sociologique, 10 (1907), pp. 48-137

Ivanova, G. M. (ed.), Labor Camp Socialism: The Gulag in the Soviet Totalitarian System (New York: M. E. Sharpe, 2000)

Jemkova, E., 'Les répressions staliniennes à Moscou et les lieux d'inhumation de masse', in É. Anstett \& L. Jurgenson (eds), Le Goulag en héritage: pour une anthropologie de la trace (Paris: Pétra, 2009), pp. 115-29

Khlevniuk, O., The History of the Gulag: From Collectivization to the Great Terror (New Haven: Yale University Press, 2000)

Kokurin, A., N. Petrov \& V. Sostakovic, Gulag Glavnoe Upravlenie Lagerei 1917-1960 (Moskva: Demokra, 2000)

Krmpotich, C., J. Fontein \& J. Harries, 'The substance of bones: the emotive materiality and affective presence of human remains', Journal of Material Culture, 15:4 (2010), pp. 371-84

Lopez Mazz, J., 'Historias desaparecidas y re aparecidas: el caso de Uruguay', in A. Zaranquin, M. Salerno \& C. Perosino (eds), Historias desaparecidas: arqueología, memoria y violencia política (Cordoba: Brujas, 2012), pp. 45-60

Naepels, M., 'Quatre questions sur la violence', L'Homme, 177-8 (2006), pp. 487-95

Ohotin, N. \& A. Roginski, Sistema ispravitel'no-trudovyh lagerei v SSSR, 1923-1960 (Moscow: Zvenia, 1998)

Panikarov, I., 'Le chemin s'arrête-t-il là?', in E. Anstett \& L. Jurgenson (eds), Le Goulag en héritage: pour une anthropologie de la trace (Paris: Pétra, 2009), pp. 131-41

Platt, T., Grave Matters: Excavating California's Buried Past (Berkeley: Heyday, 2011)

Rigeade, C., Les Sépultures de catastrophe: approche anthropologique des sites d'inhumations en relation avec des épidémies de peste, des massacres de population et des charniers militaires (BAR International S1695, internal report, 2007)

Rossi, J., Le Manuel du goulag (Paris: Le Cherche Midi, 1997)

Rousselet, K., 'Butovo: la création d'un lieu de pèlerinages sur une terre de massacres', Politix, 20 (2007), pp. 55-78

Signoli, M., 'Archéo-anthropologie funéraire et épidémiologie', Socioanthropologie, 22 (2008), published 14 October 2009, at http://socioanthropologie.revues.org/index1155.html

Signoli, M., D. Chevé, P. Adalian, G. Boëtsch \& O. Dutour, La Peste: entre épidémies et sociétés (Florence: Firenze University Press, 2007)

Van Pelt, R. J., The Case for Auschwitz: Evidence from the Irving Trial (Bloomington: Indiana University Press, 2002) 
Verdery, K., Political Lives of Dead Bodies: Reburial and Post-socialist Change (New York: Columbia University Press, 1999)

Werth, N., 'Un état contre son peuple: violences, répressions, terreurs en URSS de 1917 à 1953', in S. Courtois (ed.), Le Livre noir du communisme (Paris: Robert Laffont, 1998), pp. 41-295

Werth, N., L'Tlle aux cannibales: 1933, une déportation-abandon en Sibérie (Paris: Perrin, 2006)

Werth, N., La Terreur et le désarroi: Staline et son système (Paris: Perrin, 2007) 